\title{
Could CD8/38 predict virological response to antiretroviral therapy (ART) in human immunodeficiency virus (HIV) infected patients?
}

\author{
Umi S Intansari ${ }^{*}$, Yanri W Subronto ${ }^{2}$, Yunika Puspa Dewi ${ }^{1}$, Adika Zhulhi Arjana ${ }^{1}$, \\ Mohammad Juffrie ${ }^{3}$, Marsetyawan HNE Soesatyo ${ }^{4}$, Budi Mulyono ${ }^{1}$ \\ ${ }^{1}$ Department of Clinical Pathology, ${ }^{2}$ Department of Internal Medicine, ${ }^{3}$ Department of \\ Child ${ }^{4}$ Department of Histology and Cell Biology, Universitas Gadjah Mada/Dr. Sardjito \\ General Hospital, Yogyakarta, Indonesia.
}

DOI: http://dx.doi.org/10.19106/JMedSci004702201504

\section{ABSTRACT}

The success rate of antiretroviral therapy (ART) depends on the efficacy of the drug and the immune system's ability to control virus replication. Viral load (VL) examination is a standard test for ART monitoring. Unfortunately, this test is still very limited, especially in Indonesia. CD38 expression has been studied as a predictor for disease progression and decreases once ART is initiated. The aim of this study was to evaluate the possible usage of declining CD8/38 T-cell percentages in predicting the VL. Forty-five subjects naïve to ART were evaluated in this observational analytic study with a prospective design. Data collected included the medical history, physical examination, WHO clinical staging, complete blood counts, CD4 cell count, and plasma VL. These data then reevaluated six months after ART initiation. A paired t-test, and correlation test were used to analyze the data. Significant differences were found in all of the laboratory parameters between pre and post ART. There was a weak significant positive correlation between declining CD8/38 T-cell percentages and declining VL after 6 months of ART $(r=0.33 ; p=0.026)$, with $r^{2}=0.11$. Therefore despite the linear relationship, CD38 has limited value for prediction of VL.

\section{ABSTRAK}

Keberhasilan antiretroviral therapy (ART) tidak hanya tergantung pada efikasi obat dalam menurunkan viral load (VL) tetapi juga kemampuan sistem imun dalam mengontrol virus. Pemeriksaan VL merupakan pemeriksaan standar dalam pemantauan ART, namun ketersediaan pemeriksaan tersebut masih sangat terbatas khususnya di Indonesia. Ekspresi CD38 telah banyak diteliti sebagai prediktor perburukan penyakit dan akan menurun dengan inisiasi ART. Penelitian ini bertujuan untuk mengkaji kemungkinan penggunaan penurunan persentase sel T CD8/38 dalam memprediksi penurunan VL. Empat puluh lima subyek penelitian yang belum pernah mendapat ART dievaluasi dalam penelitian observasional analitik dengan desain prospektif ini. Data riwayat penyakit, pemeriksaan fisik, stadium klinis menurut WHO, hematologi rutin, CD4, dan VL dikumpulkan. Data ini kemudian dievaluasi ulang enam bulan pasca inisiasi ART. Uji t berpasangan dan uji korelasi digunakan untuk menganalisis data. Terdapat korelasi positif lemah bermakna 
antara penurunan persentase sel T CD8/38 dan penurunan $V L(r=0,33 ; p=0,0256)$ dengan $r^{2}=0,11$. Meskipun terdapat hubungan yang linear, kemampuan CD8/38 dalam memprediksi VL masih lemah.

Keywords: Viral load - immune activation - CD8/38 T cells - ART - HIV

\section{INTRODUCTION}

Human Immunodeficiency virus (HIV) infection is still a global health problem. Since the first acquired immune deficiency syndrome (AIDS) case was found in 1981 and HIV was identified in 1983, HIV/AIDS has become an epidemic around the world. According to the AIDS epidemic report, the number of people living with HIV/AIDS (PLHIV) in the world reached 36.9 million (34.3-41.4 million) in 2014, including 34.3 million adult PLHIV cases. Access to antiretroviral therapy (ART) has increased, with 12.9 million people receiving ART globally in 2013. Among them, 11.7 million people were from poor in developing countries. This group represented $34-38 \%$ of the 32.6 million (30.8-34.7 million) PLHIV cases that are living in poor in developing countries. ${ }^{1,2}$ Until September 2014, the cumulative cases of HIV/AIDS in Indonesia were 206,095, and 9,796 of them died. In January- September 2014, 24,645 new HIV/AIDS cases were reported. The Special Province of Yogyakarta represents the $8^{\text {th }}$ province with the highest AIDS prevalence in Indonesia; there are 26.49 cases reported per 100,000 people. $^{3}$

Antiretroviral therapy access is increasing; therefore, achieving a balance between the cost and quality of care has been a common discussion topic in developing countries. ${ }^{4}$ In developing countries with a high HIV infection prevalence similar to Indonesia, the highly active antiretroviral therapy (HAART) program has already been commenced and is administering generic drugs to reduce costs. Therefore, one question is, "Can laboratory services provide vital clinical information about the efficacy of HAART and patient's compliance towards therapeutic protocols?" Another question is, "How much will it cost to obtain this information?" reliable, and simplified flow cytometric method on single platform with 2-color (CD45+, CD4+ In developed countries, CD4 and viral load (VL) have been the practical standard to monitor patients undergoing ART; unfortunately, this exam is costly and requires competent human resources with a complete laboratory facility. ${ }^{6}$ In developing countries, a simple and affordable alternative biological marker is needed to improve the quality of clinical care for HIV infected patients.

One of the main mechanisms of HIV infection is the activation of the chronic immune response, which makes immune activation markers important for diagnosis and monitoring disease progression. It was shown that the activation of cellular immunity can be an indicator substitute for VL. This method is recommended because it is more affordable during treatment in areas with limited resources. Therefore, when facilities for the VL exam do not exist, the level of activated CD8 T cells can be used to complement and improve the prognostic value of CD4 $\mathrm{T}$ cell counts in monitoring ART. Examining CD4 and activated CD8 $\mathrm{T}$ cells uses the same EDTA blood samples and flowcytometry. Therefore, using CD8/38 $\mathrm{T}$ cell percentages 
can contribute to cost reductions when monitoring HAART. ${ }^{6}$

The aim of this study was to identify the possible usage of declining CD8/38 T-cell percentages as a marker of predicting declining VL in patients recently diagnosed with HIV 6 months post HAART.

\section{MATERIALS AND METHODS}

\section{Subjects}

Eighty newly infected HIV patients were recruited for an observational study performed at the Edelweiss Policlinic at Dr. Sardjito General Hospital, Yogyakarta and Tropical Infectious Disease Policlinic at Dr. Kariadi General Hospital, Semarang. For the purpose of our study, the inclusion criteria were designed for recipients of antiretroviral therapy who understood and agreed to be involved in the research by signing an informed consent form. The exclusion criteria were designated as a CD4 $\mathrm{T}$ cell count $<100$ cells $/ \mathrm{mm}^{3}$ and patients who refused to undergo ART.

HIV-1 infection was diagnosed on the basis of positive results from 2 HIV rapid test diagnostics and HIV antibody ELISA assays. Clinical classification of the infected HIV patients was based on the National Guidelines for the Clinical Management of HIV Infection and Antiretroviral Therapy In Adults. ${ }^{7}$ This study was conducted in accordance with the Declaration of Helsinki and was approved by the Health Research Ethics Committee of the Faculty of Medicine, Universitas Gadjah
Mada and was granted permission by the Director of Dr. Sardjito General Hospital, Yogyakarta and Dr. Kariadi General Hospital, Semarang. Antiretroviral therapy was defined as an antiretroviral therapy consisting of 2 nucleoside analogues and 1 nonnucleoside analogue. There was no strict approach to antiretroviral treatment; however, each intern administered the appropriate ART regimen and changed the drugs according to his or her interpretation of the patient's data and on the basis of Indonesian guidelines.

Patient data were collected on standardized clinic forms and entered into a customized electronic record database. Baseline evaluations included the medical history, physical examination, WHO clinical staging, complete blood counts, CD4 cell count, and plasma VL. These same clinical and laboratory evaluations were performed 6 months after ART initiation to determine the therapy responses.

\section{Laboratory examinations}

$\mathrm{T}$ lymphocyte subsets were quantified by flow cytometry using a Becton Dickinson FACSCalibur. Three milliliters of freshly isolated peripheral blood was analyzed per patient. Whole blood was stained with fluorochrome-conjugated monoclonal antibodies: CD3-FITC, CD4-PE, and CD45PerCP for CD4 T cells and CD8-FITC, CD38$\mathrm{PE}$, and CD45-PerCP for CD8/38 T cells. The gating strategy for $\mathrm{CD} 8 / 38 \mathrm{~T}$ cells is shown in FIGURE 1. 

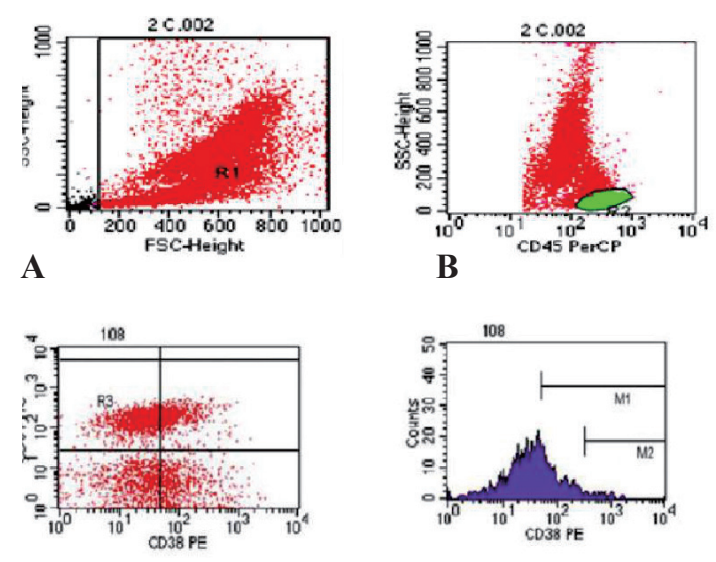

C

D

FIGURE 1. CD8/38 flowcytometry gating strategy

The HIV-1 RNA levels were measured using quantitative RT-PCR, Roche COBAS $\AA$ AmpliPrep/COBAS ${ }^{\circledR} \quad$ TaqMan ${ }^{\circledR} \quad$ HIV-1 Test, v2.0 (Roche, Branchburg, NJ, limit of detection (LOD) 20 copies $/ \mathrm{mL}$ ). Six milliliters of fresh EDTA blood were centrifuged at 3000 rpm for 15 minutes to obtain plasma. Plasma was stored in a $-80 \mathrm{oC}$ freezer until the target number of samples was reached. The stored plasma was sent to the Dharmais Cancer Hospital, Jakarta, for VL examination.

\section{Statistical analysis}

Data were monitored for authenticity and accuracy and then were coded, tabulated and entered into a computer program. Continuous data were presented as the mean \pm standard deviation (SD) if the data distribution was normal or the median (min-max) if the data distribution was abnormal; however, categorical data were presented as frequencies and proportions. Statistical analysis used a paired t-test, and Spearman's correlation test.

\section{RESULTS}

The clinical characteristics of the 45 newly infected HIV patients prior to baseline are presented in TABLE 1. Among the 45 treatment-naïve HIV-infected patients contributing to these analyses, $86.7 \%$ were male, $66.7 \%$ were homosexual, and $52.3 \%$ were at clinical stage 1 , and the median age was 28 (19 to 51) years old.

TABLE 1. Baseline characteristics of subjects

\begin{tabular}{lcc}
\hline \multicolumn{1}{c}{ Variable } & $\mathrm{n}$ & $\%$ \\
\hline Age $($ median \pm SD) & $28(19-51)$ & \\
\hline Sex & & \\
Male & 39 & $86.7 \%$ \\
Female & 6 & $13.3 \%$ \\
Risk Factor & & \\
Heterosexual & 27 & $61.4 \%$ \\
Homosexual & 19 & $43.2 \%$ \\
Injection & 3 & $6.8 \%$ \\
Clinical Stage & & \\
1 & 25 & $55.6 \%$ \\
2 & 15 & $33.3 \%$ \\
3 & 4 & $8.9 \%$ \\
\hline
\end{tabular}

Prior to starting HAART, the mean CD4 $\mathrm{T}$ cell count and percentage were $288 \pm 131$ cells/uL and $14.96 \pm 5.91 \%$, respectively; the median VL was 67,400 (49.675-105.649) copies $/ \mathrm{ml}$; and the median percent of activated CD8 + T cells (CD8/38) was $45.30 \%$ 
(40.99-54.10\%). After 6 months of ART, both VL and the percent of CD8/38 T cells were decreased with an increased CD4 $\mathrm{T}$ cell count and percentage. There were significant differences between pre and post ART in all of the immunological and virological parameters
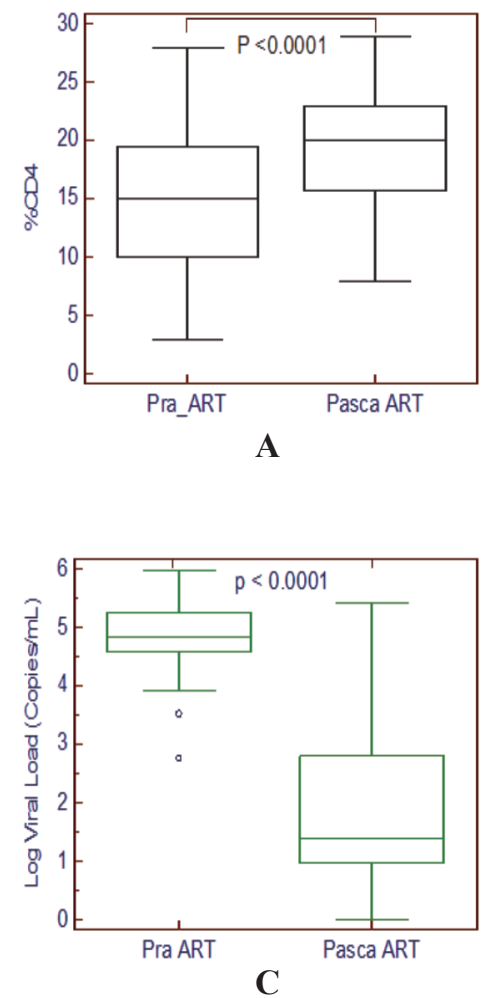

FIGURE 2. Pre and post analysis of imunological and virological parameter.

\section{DISCUSSIONS}

Similar to most viral infections, HIV infections activate $\mathrm{T}$ and B-cells, which increase CD38 expression as well as other immune activation markers. ${ }^{8}$ Currently, CD38 has been studied from a prognostic point of view in HIV-1 infections. CD38 expression is high in peripheral lymphocytes during a primary infection, decreases in the transition to the asymptomatic phase, and finally increases when the disease develops into AIDS. High
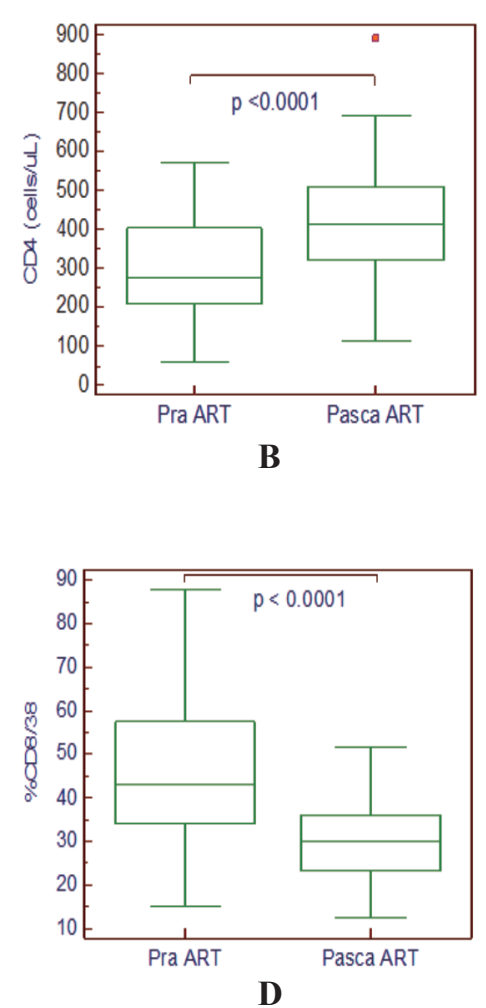

(FIGURE 2). Six months post ART, the mean CD4 $\mathrm{T}$ cell count and percentage were $433 \pm$ 150 cells/ uL and $19.27 \pm 5.74 \%$, respectively, and the median VL and percent of CD8/38 were 25 (0.0-97) copies/mL and 30.11 (27.04$33.89) \%$, respectively. 
persistently high levels of activated immune cells may have resulted from ongoing virus replication, despite the lower levels. In addition, co-infection from other viruses, such as cytomegalovirus and Epstein-Barr virus, are a consequence of mucosal immune dysfunction due to decreased CD4 T-cells in the acute phase and the loss of intestinal barriers that may translocate bacteria to systemic circulation. ${ }^{12}$

The results from this study align with Maartens et al. ${ }^{11}$ after initiating ART, the VL levels decreased below the equipment's minimum limit of detection in almost all of the patients during the 3 months of ART. ${ }^{11}$ These results support the antigen stimulation theory. Human immunodeficiency virus antigens were dominant in causing immune activation during HIV infection. The declining CD8/38 $\mathrm{T}$ cell percentages 6 months post ART was positively correlated with declining VLs $(\mathrm{r}=0.33 ; \mathrm{p}=0.0256 ; \mathrm{r} 2=0.109)$ and (FIGURE $3)$. This correlation was weak and showed that only $11 \%$ proportion of declining VL was could be explained by the declining CD8/38 percentage. On the contrary, there was no significant correlation $(r=0.15, p=$ 0.32 ) between declining VL and CD4 T cell recovery after 6 months of ART.

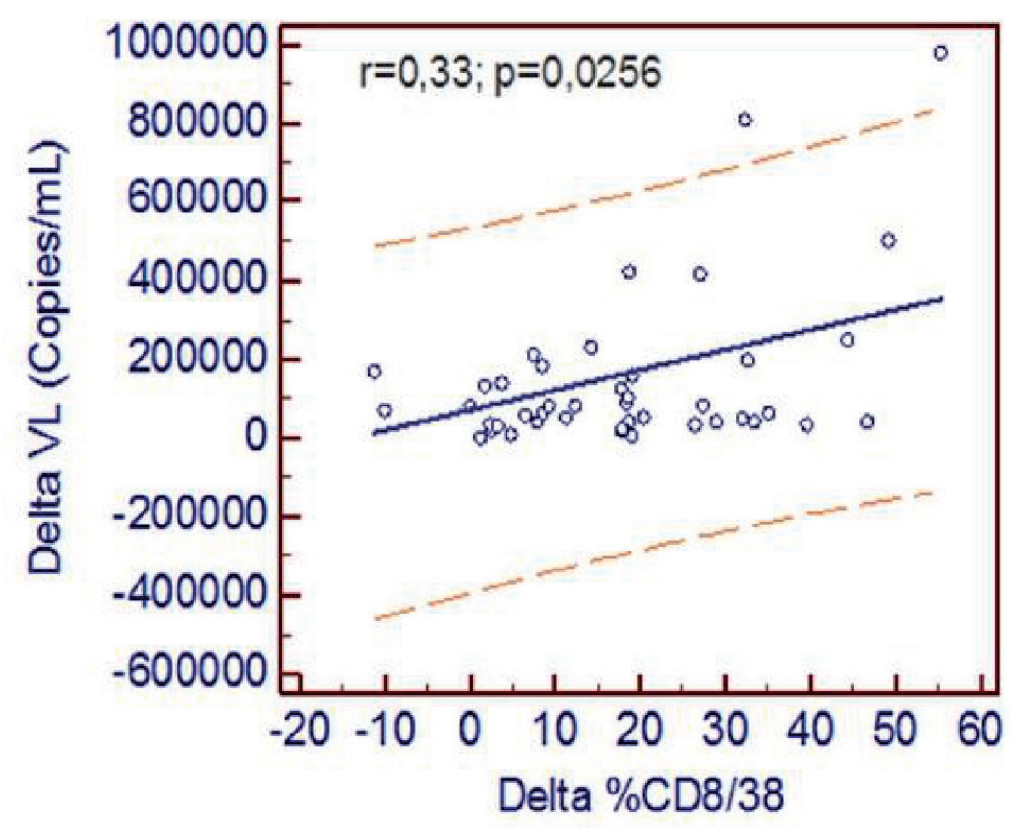

FIGURE 3. Correlation between the declining of $\mathrm{CD} 8 / 38 \mathrm{~T}$ cell percentages and viral load

CD38 expression in CD8 T-cells is a marker for activated lymphocytes and can predict the progression of the disease. ${ }^{2} \mathrm{Up}$ regulation of $\mathrm{CD} 38$ in $\mathrm{CD} 8 \mathrm{~T}$-cells reflects a dynamic interaction between HIV and immune responses. ${ }^{13}$. In this study, we found a weak but significant correlation between declining CD8/38 T cells and VL 6 months post ART. The CD8/38 percentage accounted for only $11 \%$ of variance in VL which was low. Therefore, although there was a parallel decline of CD8/38 cell percentage and VL in response to ART, the relationship (correlation) has limited value for prediction and not 
adequately serve as a surrogate marker for VL testing. Our results were consisted with Steel et al, 2008 that showed poor specificity of elevated $\mathrm{T}$ cell activation to detect viremia. These result suggest that factors unrelated to viral replication may play a role in $\mathrm{CD} 38$ expression on CD8 T cells. ${ }^{14}$

The percentage of CD8/38 $\mathrm{T}$ cell might be used to determine which patients are at risk of having viraemia after treatment and should be used to complement CD4 $\mathrm{T}$ cell counts, the only laboratory examination for monitoring ART in developing countries. The immunological criteria cannot be used to predict virological failure, cannot identify almost half of the patients with treatment failure and incorrectly identified almost half of the patients with immunological failure with suppressed VL level. Due to this limitation, only monitoring ART by CD4 $\mathrm{T}$ cell counts will cause drug resistant accumulation and unnecessary drug switches. This will increase the costs of the national HIV program. ${ }^{4,15}$ The discordant results between virological and immunological responses were influenced by age, CD4 T cells and VL levels pre ART, ART regiments, and co-infection. ${ }^{16,17}$

CD38 expression in CD8 T-cells differs in populations with genetic variations. Expression levels may be influenced by genetics and the environment; therefore, close matching is needed with the control group for the same population to determine the normal value. This study limitations included having no healthy control group, imbalanced HIV stages patient proportion and a short monitoring period for ART responses.

\section{CONCLUSIONS}

We found a significant but weak correlation between declining CD8/38 T cell percentages and VL 6 months post ART in patients with
HIV. Despite the parallel decline of both CD8/38 percentage and VL, the CD8/38 percentage had limited value for prediction of virological response to ART. CD8/38 T cell percentages might be used serially for ART monitoring as a complementary laboratory examination to $\mathrm{CD} 4 \mathrm{~T}$ cell count in the area at which VL testing is limited and expensive.

\section{ACKNOWLEDGEMENTS}

Funding for this study was provided by the Ministry of Research, Technology and Higher Education of the Republic of Indonesia through University Excellent Research Program.

\section{REFERENCES}

1. WHO. HIV reporting: global update on the health sector response to HIV. Geneva: WHO Press, 2014.

2. Ostrowski SR. Immune activation in chronic HIV infection. Dan Med Bull 2010; 57(3):B4122.

3. Ditjen PP \& PL Kemenkes RI. Statistik kasus HIV/AIDS di Indonesia. Jakarta: Kemenkes RI, 2014.

4. Rawizza HE, Chaplin B, Meloni ST, Eisen G, Rao T, Sankale JL, et al. Immunologic criteria are poor predictors of virologic outcome: implications for hiv treatment monitoring in resource-limited settings. Clin Infect Dis 2011; 53(12):1283-90. Doi: $10.1093 / \mathrm{cid} /$ cir729.

5. Glencross DK, Janossy G, Coetzee LM, Lawrie D, Scott LE, Sanne I, et al. CD8/ CD38 activation yields important clinical information of effective antiretroviral therapy: findings from the first year of the CIPRA-SA cohort. Cytometry B Clin Cytom 2008; 74 (Suppl 1):S131-40. http://dx.doi.org/10.1002/ cyto.b.20391.

6. Ondoa P, Koblavi-Deme S, Borget MY, Nolan ML, Nkengasong JN, Kestens L. Assessment of CD8 T cell immune activation 
markers to monitor response to antiretroviral therapy among HIV-1 infected patients in Côte d'Ivoire. Clin Exp Immunol 2005; 140(1):138-48. http://dx.doi.org/10.1111/ j.1365-2249.2005.02734.x

7. Kementerian Kesehatan Republik Indonesia. Pedoman Nasional tatalaksana klinis infeksi HIV dan terapi antiretroviral pada orang dewasa. Jakarta: Kemenkes RI, 2011.

8. Savarino A, Bottarel F, Malavasi F, Dianzani U. Role of CD38 in HIV-1 infection: an epiphenomenon of T-cell activation or an active player in virus/host interactions? AIDS 2000; 14(9):1079-89. http://dx.doi. org/10.1097/00002030-200006160-00004

9. Deeks SG, Kitchen CM, Liu L, Guo H, Gascon R, Narváez AB, et al. Immune activation set point during early $\mathrm{HIV}$ infection predicts subsequent CD4+ T-cell changes independent of viral load. Blood 2004; 104(4):942-7. http:// dx.doi.org/10.1182/blood-2003-09-3333

10. Sukwit S, Chuenchitra T, Rojanasang P, Wiwattanakul S, Saksopin L, Srisurapanon S. Distribution of CD38 Molecules on CD3+ and CD8+ T- lymphocyte in adulthood HIV1-uninfected Thais. J med Assoc Thai 2005; 88(5):48-55.

11. Maartens G, Celum C, Lewin SR. HIV infection: epidemiology, pathogenesis, treatment, and prevention. Lancet 2014; 384(9939):258-71. Doi: 10.1016/S01406736(14)60164-1.

12. Hattab S, Guihot A, Guiguet M, Fourati S, Carcelain G, Caby F, et al. Comparative impact of antiretroviral drugs on markers of inflammation and immune activation during the first two years of effective therapy for HIV-1 infection: an observational study.
BMC Infect Dis 2014; 14(122):1-9. http:// dx.doi.org/10.1186/1471-2334-14-122

13. Benito JM, López M, Lozano S, Ballesteros C, Martinez $\mathrm{P}$, González-Lahoz $\mathrm{J}$, et al. Differential upregulation of CD38 on different T-cell subsets may influence the ability to reconstitute CD4+ T cells under successful highly active antiretroviral therapy. J Acquir Immune Defic Syndr 2005; 38(4):373-81.

h t t p://dx.doi.org/10.1097/01. qai.0000153105.42455.c2

14. Steel A, John L, Shamji MH, Henderson DC, Gotch FM, Gazzard BG, et al. CD38 expression on $\mathrm{CD} 8 \mathrm{~T}$ cells has a weak association with CD4 T-cell recovery and is a poor marker of viral replication in HIV-1infected patients on antiretroviral therapy. HIV Med 2008; 9(2):118-25. http://dx.doi. org/10.1111/j.1468-1293.2007.00528.x

15. Rosso R, Fenoglio D, Terranova MP, Lantieri F, Risso D, Pontali E, et al. Relevance of CD38 Expression on CD8 T Cells to Evaluate Antiretroviral Therapy Response in HIV- 1-infected youths. Scand J Immunol 2010; 71(1):45-51. http://dx.doi. org/10.1111/j.1365-3083. 2009.02345.x

16. Tuboi SH, Brinkhof MW, Egger M, Stone RA, Braitstein P, Nash D, et al. Discordant responses to potent antiretroviral treatment in previously naive HIV-1-infected adults initiating treatment in resource-constrained countries: the antiretroviral therapy in lowincome countries (ART-LINC) collaboration. J Acquir Immune Defic Syndr 2007; 45(1):529. http://dx.doi.org/10.1097/QAI.0b013e 318042e1c3

17. Kumar RS. Immunovirological discordance in HIV. Med Update 2012;22:89-93. 